\title{
Spatial Analysis of Outdoor Tobacco Advertisement Around Children and Adolescents in Indonesia
}

\author{
Susy K. Sebayang ${ }^{1,2 *}$, Desak Made Sintha Kurnia Dewi ${ }^{1,2}$, Septa Indra \\ Puspikawati $^{2,3}$, Erni Astutik ${ }^{2,4}$, Soenarnatalina Melaniani ${ }^{2,4}$, Dian Kusuma ${ }^{5}$
}

${ }^{I}$ Department of Epidemiology, Biostatistics, Population Studies and Health Promotion, Faculty of Public Health, Universitas Airlangga, Banyuwangi Campus, Banyuwangi, Indonesia

${ }^{2}$ Research Group for Health and Wellbeing of Women and Children, Faculty of Public Health, Universitas Airlangga, Banyuwangi Campus, Banyuwangi, Indonesia

${ }^{3}$ Department of Nutrition, Faculty of Public Health, Universitas Airlangga, Banyuwangi Campus, Banyuwangi, Indonesia

${ }^{4}$ Department of Epidemiology, Biostatistics, Population Studies and Health Promotion, Faculty of Public Health, Universitas Airlangga, Surabaya, Indonesia

${ }^{5}$ Centre for Health Economics \& Policy Innovation, Imperial College Business School, London, United Kingdom

*Corresponding Author:

Susy K. Sebayang

Research Group for Health and Wellbeing of Women and Children

Department of Biostatistics and Population Studies

Faculty of Public Health Universitas Airlangga Banyuwangi Campus

Jl. Wijaya Kusuma No. 113 Banyuwangi, 68425 East Java, Indonesia

Email: sksebayang@fkm.unair.ac.id

Phone: +6281288283367

Author's contribution:

Susy K. Sebayang designed the study, conducted data collector training, designed data architecture, conducted data cleaning and analysis, and prepared the manuscript. Desak Made Sintha Kurnia Dewi helped design the study, conducted training, data analysis and revised the manuscript. Septa Indra Puspikawati and Erni Astutik helped design the study, conducted training, coordinated field data collection, conducted data cleaning, and revised the manuscript. Soenarnatalina Melaniani helped design the study and revised the manuscript. Dian Kusuma helped design the study and analysis, and revised the manuscript. 


\begin{abstract}
There is a major gap of action by the Indonesian government to control tobacco advertisement. This study aimed to describe and compare outdoor tobacco advertisements (OTAs) in locations with and without OTA bans in relation to their proximity to children and adolescents. Global positioning system coordinates of all OTAs visible from the streets in Banyuwangi and Surabaya in East Java province were collected and analysed to determine their density at $0-100,>100-300$ and $>300-500 \mathrm{~m}$ from facilities used by children and adolescents. Hotspot analysis was conducted to identify places with exceptionally high densities of OTAs. The number and density of OTAs in Surabaya, where there was no policy for controlling OTAs, were greater than those in Banyuwangi, where OTAs were partially banned. Regardless of the existence of a ban, OTAs were 2.6-3.4 times denser in areas closer to facilities used by children and adolescents than further apart. The OTA point hotspots approximated the hotspots of tobacco retailers and facilities used by children and adolescents in both locations. A partial ban may only have a small impact. A total advertising ban, including at point of sale, should be encouraged for both locations for optimal protection of children and adolescents.
\end{abstract}

Keywords: outdoor tobacco advertisement, advertisement density, adolescent, Indonesia 


\section{Introduction}

Indonesia is the only country in Asia that has neither signed nor ratified the Framework Convention on Tobacco Control. Unsurprisingly, tobacco control regulations in Indonesia remain weak, and the prevalence of smoking remains high. The latest national survey in Indonesia reported that $55.8 \%$ of males and $1.9 \%$ of females smoked (Badan Penelitian dan Pengembangan Kesehatan Kementerian Kesehatan Republik Indonesia, 2019). The same survey reported that 9.1\% of children aged 10-18 years smoked, an increase from 8.8\% reported in the 2016 national survey. This number is far from the target of the government to reduce smoking among children and adolescents to $5.4 \%$ by 2019 (Badan Penelitian dan Pengembangan Kesehatan Kementerian Kesehatan Republik Indonesia, 2016).

A ban on tobacco advertisement, promotion and sponsorship (TAPS) as one of the recommended tools for countries to reduce smoking has been half-heartedly pursued. Tobacco advertising in Indonesia remains prevalent, creative and aggressive (Susy K Sebayang et al., 2012), promoting associations between smoking and emotional control and using various themes, such as masculinity, modernity and traditional values (Nichter et al., 2009). A 2017 survey of 10 cities found 2,868 TAPS located in routes that children and adolescents use when going to school, extracurricular lessons, shopping centres, religious sites or social settings (Sundari et al., 2017). The findings from the Global Youth Tobacco Survey reveal that these promotions are effective, as $50 \%$ of Indonesian children and adolescents reported noticing tobacco advertising at the point of sale (World Health Organization, 2015). Some conventional tobacco advertisements have even started to use ways to link to the Internet and social media to reach millennials (Astuti et al., 2019).

Systematic reviews and meta-analyses report that exposure to tobacco product displays at the point of sale increases both smoking and susceptibility to smoking (Robertson et al., 2016; Robertson et al., 2015). Cumulative exposure to TAPS was linked to increased odds of smoking among Nigerian children and adolescents (Chido-Amajuoyi et al., 2017). In Indonesia, 32.4\% of the 1,943 high school students surveyed reported that at least 1 out of 15 cigarette advertisements they saw encouraged them to smoke (Prabandari \& Dewi, 2016). Compliance with even partial restriction of outdoor tobacco advertisements (OTAs) at the point of sale in India was associated with lower smoking prevalence among students (Mistry et al., 2019).

The Indonesian Government Regulation No. 109/2012 restricts the design and placement of OTAs in Indonesia and gives local governments the authority to regulate OTAs in their areas. Although local governments levy tax on outdoor advertisement in their areas, the income generated from OTAsmakes up only a small portion of the local government's income (Yulianty et al., 2011). Despite all the evidence above, currently less than $10 \%$ of the 514 districts and cities in Indonesia have enacted bans on OTAs.

In 2016, the Head of Banyuwangi District issued Regent's Regulations (Peraturan Bupati/Perbup) to ban OTAs in all Banyuwangi Subdistrict area, selected main roads, and sport arenas and any advertisements within $25 \mathrm{~m}$ of schools and religious sites. An evaluation of ban enforcement one year after its implementation found a total of 667 advertisement points on main roads and parks where OTAs were banned (S. K. Sebayang et al., 2018). As the evaluation survey was designed to count violations only in places where OTAs were banned, the evaluation 
did not represent the total number and density of advertisements in the area.

A study on the density of OTAs in Surabaya, a city that does not ban OTAs, was published recently (Megatsari et al., 2019). This study, however, only counted medium- and large-sized advertisements in the form of videoboard, billboard, and banner and therefore did not represent the real condition of OTAs in Indonesia. Both Banyuwangi and Surabaya are located in East Java, a province that produces the most tobacco in Indonesia with a total of 82,524 tons of dried tobacco leaf, and has the largest tobacco plantation with an area of 100,058 ha in 2019 (Center for Agricultural Data and Information System, 2019) . It is important to understand the difference in the amount of stimulation to smoking faced by children and adolescents in cities with partial ban and without any ban on OTAs in order to assess whether partial ban makes much difference in the advertisement density around children and adolescents. This study therefore describes and compares the visibility and density of all types and sizes of OTAs around sites used by children and adolescents in Banyuwangi a district that partially bans tobacco advertisement, and Surabaya, a city that has no regulations on tobacco advertisement.

\section{Materials and Methods}

\section{Study Design}

The study was conducted in Banyuwangi District (representing a location with an OTA ban) and Surabaya City (representing a location without an OTA ban) from July to September 2019. In line with the Indonesian requirements, permits for the study were granted by the local government of Banyuwangi District and Surabaya City, while the Ethics Committee of the Faculty of Public Health of Universitas Airlangga approved the study.

Banyuwangi District covered 5,782.5 km2 in total area comprising of 25 subdistricts and was inhabited by 1.6 milion people (Badan Pusat Statistik Kabupaten Banyuwangi, 2019), while the total area of Surabaya City was $326.8 \mathrm{~km} 2$ comprising of 31 subdistricts and the total population was 2.6 million people (Badan Pusat Statistik Kota Surabaya, 2017). We first selected Banyuwangi Subdistrict in Banyuwangi District, as it has the highest population density and a high density of schools. Banyuwangi Subdistrict is also the capital town of Banyuwangi District, where the Banyuwangi District Government Office resides. We expect any implementation of policy including tobacco advertisement ban will take impact here first.

Subsequently, we listed subdistricts in East Surabaya Region, as it has the highest number of schools in Surabaya City, and selected a subdistrict with a population similar to that of Banyuwangi Subdistrict. We then selected one contiguous subdistrict each for the selected locations. This resulted in four subdistricts as study locations: Banyuwangi and Giri Subdistricts in Banyuwangi District and Sukolilo and Mulyorejo Subdistricts in Surabaya City.

We observed all forms of advertising including banners, posters, billboards, video advertisements, outdoor advertisements on stores, stickers, merchandise and any other items containing tobacco brand logos that were visible from the street in all areas of the selected subdistricts. Banyuwangi and Giri Subdistricts were evaluated in 2017 (S. K. Sebayang et al., 
2018), one year after the launch of tobacco advertisement ban, and thus we were able to compare between the number of advertisement in 2017 and in 2019 in these subsample locations.

\section{Data Collection}

Four teams of two trained enumerators in Banyuwangi and five teams of two trained enumerators in Surabaya surveyed all the areas of study locations on foot or on a motorbike and collected GPS coordinates and photographs of OTAs and facilities used by children and adolescents using an Android-based data collection application (KoboToolBox, 2012). The enumerators used Google Map to identify the boundary of the study locations. Data collected and coverage were checked by field coordinators and area supervisors (SIP and EA) every day. A quality control team revisited randomly selected GPS coordinates sent from the mobile application into the server to ensure that the location and information entered into the server were correct.

\section{Data Analysis}

We used two measures to calculate the number of OTAs: the number of advertisement points (OTA points) and the number of advertisement materials (OTA materials) visible. An OTA point is a spot where a cluster of advertisements for the same brand and type is found. For example, three posters advertising the same Dunhill brand in the same location count as one advertisement point. The number of advertisement materials is the total number of all advertisement materials. For example, three posters for a similar Dunhill brand found in the same location equal three advertisement materials. A store-affiliated advertisement is an advertisement placed on any part of a store that is visible from the street. We included banners and store name boards using the terms Sampoerna Retail Community (SRC) or Gudang Garam Strategic Partnership (GGSP) or Djarum Retail Partnership (DRP) as a form of tobacco advertisement. SRC, GGSP and DRP are retailer programmes established by Sampoerna, Gudang Garam and Djarum, three of the largest tobacco companies in Indonesia.

Descriptive analysis was conducted to assess the number of OTAs according to the type of OTA and the tobacco company, the density of OTAs according to the number of children and adolescents and the density of OTAs according to area and their proximity to facilities used by children and adolescents. Facilities used by children and adolescents included schools (primary, middle and high school and higher education level as well as nonformal education), other gathering sites (play groups, kindergartens, child-care centres, quranic schools and playgrounds), sport centres, recreation centres and places of worship.

The analysis was conducted using STATA 15. The number of neighbouring OTA points was calculated using the geonear command (Picard, 2010) for areas within a radius of 0-100, >100300 and $>300-500 \mathrm{~m}$, adjusting for the Earth's radius at the equator. The distance of 100 and 300 $\mathrm{m}$ were chosen for comparability with a previous report from Surabaya (Megatsari et al., 2019). We estimated that children and adolescents can walk comfortably for a maximum distance of 500 metres and thus used this as the maximum distance. Density was calculated by dividing the number of neighbouring OTA points by the area within the radius in square kilometres. Districtlevel data on area in square kilometres and populations of children and adolescents were 
obtained from reports from local statistics bureaus (Badan Pusat Statistik Kabupaten Banyuwangi, 2018a, 2018b; Badan Pusat Statistik Kota Surabaya, 2018, 2019).

For hotspot analysis, the study areas were divided into grids of 500 x $500 \mathrm{~m}$. Getis-Ord Gi* spatial statistics was used to identify grids with significantly higher number of OTA points compared to neighbouring grids with 5\% and 1\% significance level. Hotspot analysis was done using Hotspot Analysis plugin (Oxoli et al., 2017) in QGIS 2.8.

\section{Results}

In Banyuwangi, there were 1,301 OTA points out of a total of 2,594 points of any outdoor advertisements $(50.2 \%$ ), of which $95.3 \%$ were store affiliated. In total there were 1,838 OTA materials in Banyuwangi. In locations that were surveyed in 2017 during one year evaluation of the OTA ban in Banyuwangi, there were 131 OTA points in 2019, of which $93 \%$ were store affiliated. In Surabaya, there were 2,339 OTA points out of a total of 5,267 points of outdoor advertisements (44.4\%), of which $88.5 \%$ were store affiliated. The total number of OTA materials in Surabaya was 3,700 (Table 1). The density of OTA according to the area and population of children and adolescents was greater in Surabaya than in Banyuwangi. There were 2.6 times more OTA points and 2.9 times more OTA materials per square kilometre and 1.3 times more OTA points and 1.4 times more OTA materials per 1,000 children and adolescents in Surabaya than in Banyuwangi (Table 1).

In both cities, banners and posters were the most prevalent types of tobacco advertisement, but other types, such as merchandise, X-banners and painted walls, were more prevalent in Surabaya than in Banyuwangi (Table 1). Djarum had the highest share of OTAs in both cities $(34.1 \%$ of spots in Banyuwangi and 20.4\% in Surabaya), followed by Gudang Garam in Banyuwangi and Karya Dibya Mahardika (part of Japan Tobacco Inc.) in Surabaya. HM Sampoerna (part of Philip Morris International) had the third highest number of OTAs in Banyuwangi and had the fourth highest number in Surabaya. There were more OTAs placed by other smaller companies in Surabaya than in Banyuwangi (Table 1). OTAs showing SRC $(\mathrm{n}=41$ in Banyuwangi and $\mathrm{n}=25$ in Surabaya) and GGSP ( $n=11$ in Banyuwangi and $n=48$ in Surabaya), but no OTAs showing DRP, were found in both locations.

In Banyuwangi, 22 of 110 schools and 53 of 260 religious sites had at least one neighbouring OTA within $25 \mathrm{~m}$ radius. In this district, $70.3 \%$ of all facilities used by children and adolescents had at least one OTA point within $100 \mathrm{~m}$, and $97.7 \%$ had at least one OTA point within $>100$ $300 \mathrm{~m}$. Most schools (98.2\%) had at least one neighbouring OTA point within $>100-300 \mathrm{~m}$. In fact, all middle schools, high schools, higher education level entities, recreation centres and other sites used by children and adolescents, such as preschools, kindergartens, quranic schools and playgrounds, had at least one neighbouring OTA point at $>100-300 \mathrm{~m}$. Among all places of worship, 75\% had OTA points within 0-100 $\mathrm{m}$ and 97\% within >100-300 $\mathrm{m}$ (Table 2).

In Surabaya, $68.1 \%$ of all facilities used by children and adolescents had at least one OTA point within $100 \mathrm{~m}, 92.7 \%$ had at least one OTA point within $>100-300 \mathrm{~m}$, and $97 \%$ had at least one OTA point within $>300-500 \mathrm{~m}$. Only slightly better than in Banyuwangi, more than half of schools $(56.1 \%)$ had a neighbouring OTA point within $100 \mathrm{~m}$, and $90 \%$ had a neighbouring OTA 
point at >100-300 m. All middle schools and higher education entities had at least one neighbouring OTA point at $>300-500 \mathrm{~m}$, and $98 \%$ of other sites used by children and adolescents had at least one neighbouring OTA point at $>300-500 \mathrm{~m}$. Similar to Banyuwangi, $97.5 \%$ of places of worship had at least one OTA point at $>100-300 \mathrm{~m}$, but more $(82.9 \%)$ had at least one OTA point within 0-100 m when compared to Banyuwangi (Table 2).

In Banyuwangi, the density of OTAs per square kilometre increased as the distance from a facility used by children and adolescents decreased. In total, there were $50.8 \mathrm{OTAs} / \mathrm{km}^{2}$ at $>300$ $500 \mathrm{~m}$, and the density increased to $62.2 / \mathrm{km}^{2}$ at $>100-300 \mathrm{~m}$ and reached $93.8 / \mathrm{km}^{2}$ at less than $100 \mathrm{~m}$ from the facility. The greatest increase in density occurred around higher education entities and places of worship, with 2.6 and 2 times, respectively, higher density of neighbouring OTAs at 0-100 m compared with $>300-500 \mathrm{~m}$ (Table 2). The increase in density of OTAs per square kilometre with decreasing distance from the facility was greater in Surabaya than in Banyuwangi. In Surabaya, there were $89.2 \mathrm{OTAs} / \mathrm{km}^{2}$ at $>300-500 \mathrm{~m}$, increasing to $113.3 / \mathrm{km}^{2}$ at $>100-300 \mathrm{~m}$ and reaching $225.9 / \mathrm{km}^{2}$ at less than $100 \mathrm{~m}$ from the facility. The greatest increase in density occurred around places of worship, gathering sites of children and adolescents and primary schools, with 3.4, 2.9 and 2.3 times, respectively, higher density of neighbouring OTAs at 0-100 m compared with >300-500 $\mathrm{m}$ (Table 2).

There was one large hotspot of significantly high numbers of OTA points in Banyuwangi and two hotspots in Surabaya. In Banyuwangi, the hotspots with 1\% significance level covered an area of $2.25 \mathrm{~km}^{2}$ and reached $4.25 \mathrm{~km}^{2}$ when using a significance level of $5 \%$. In Surabaya, the hotspots with $1 \%$ significance level covered an area of $1 \mathrm{~km}^{2}$ and reached $2.75 \mathrm{~km}^{2}$ when using a significance level of 5\% (Figure 1). More facilities used by children and adolescents were within the OTA point hotspots in Banyuwangi compared to Surabaya. The facilities within OTA point hotspots were mostly place of worships in Banyuwangi and schools in Surabaya. The locations of OTA point hotspots in Banyuwangi were similar with the locations of hotspots of tobacco retailers and facilities used by children and adolescents. In Surabaya, one of the OTA point hotspot locations were within the hotspots of tobacco retailers and facilities used by children and adolescents (Figure 2).

\section{Discussion}

\section{General Findings}

Our study found that the number and density of OTAs in Surabaya, where there was no policy for controlling tobacco advertisements, were greater than in Banyuwangi, where tobacco advertisement was banned in some locations. However, even with the partial OTA ban in Banyuwangi, the proportion of facilities used by children and adolescents with at least one neighbouring OTA within all radius was not markedly different between the two locations. In addition, the density of OTAs increased as the distance to a facility used by children and adolescents decreased in both locations. This indicates that the children and adolescents in both locations were surrounded and targeted by OTAs. The coverage of OTA point hotspots and the number of facilites used by children and adolescents within the hotspot was larger in Banyuwangi than in Surabaya. The OTA point hotspots approximated the hotspots of tobacco 
retailer and facilities used by children and adolescents in both cities, indicating an association between OTA placement and retail locations.

\section{Comparison with Other Studies}

A study conducted in New York City in 2015 found 1,077 OTAs that made up 6.6\% of all advertisement of consumable products in that city (Adjoian et al., 2019). Although Surabaya and Banyuwangi are much smaller in population than New York, we found more OTAs in our study sites. A previous study in Banyuwangi found a violation of regulations one year after the OTA ban was made effective (S. K. Sebayang et al., 2018). This study revealed that the violation around schools still occurred in 2019, 3 years after the ban was made effective. However, the number of OTA points found in 2019 was much less than the 2017 survey that found 667 OTA points. It is also important to note that the percentage of store-affiliated OTA increased from $79.9 \%$ in 2017 to $93 \%$ in 2019 (S. K. Sebayang et al., 2018). Similar to our observations, a study in India reported that $20 \%$ of stores within $100 \mathrm{~m}$ from a school still placed tobacco advertisements on the outside of the store despite the restriction on the sale of tobacco products within $100 \mathrm{~m}$ of schools (Balappanavar et al., 2017). As we calculated all types and sizes of advertisements our study found a larger number of advertisements only in two subdistricts in Surabaya compared to what was reported from a study of 31 subdistricts in the same city that found 307 large- and medium-sized OTAs, including billboards, banners and video advertisement (Megatsari et al., 2019).

\section{Possible Mechanisms}

The number of tobacco advertisement points in locations previously evaluated in Banyuwangi was reduced from 667 in 2017 (S. K. Sebayang et al., 2018) to 131 in 2019, indicating the impact of the regulation. It is therefore not surprising to find much greater numbers and densities of OTAs in Surabaya, where such regulation does not exist. However, the small differences in the percentage of facilities with neighbouring OTAs between Banyuwangi and Surabaya, as well as the similar trend in both locations of increasing OTA density with decreasing distance to facilities used by children and adolescent, indicate that a partial ban may not be enough to ensure sustainable protection against tobacco advertising exposure.

The higher percentage of store-affiliated OTAs in Banyuwangi compared with that found in 2017 survey may be the tobacco industry's response to the regulation. Currently, although they are clearly visible from the street, advertisements on stores are still a grey area in the policy, as there is a loophole in Government Regulation No. 109/2012 that allows placement of advertisements where tobacco is sold. Tobacco companies seem to use this loophole as seen by the similarities in location between OTA hotspots and tobacco retailer hotspots. Tobacco companies, such as HM Sampoerna, Gudang Garam and Djarum, have also responded by placing advertisements of their retailer programs on store name banners or billboards using the retailer program symbols instead of using specific tobacco product brands, possibly to avoid being classified as tobacco advertisements but rather as store signs. Such retailer programs signs retailers to contracts for some amount of money and incentives such as store makeover and packages of gifts like T-shirts, ashtrays, umbrellas and clocks in exchange for placement of 
cigarette pack display and retailer program banner at their stores without any real sales target (Ikatan Ahli Kesehatan Masyarakat Indonesia, 2017).

The small difference between the two locations in the percentage of facilities with neighbouring OTA, the higher density of OTA in areas closer to facilities used by children and adolescents and the approximate location of OTA hotspots may also be a reflection of tobacco retail distribution and a strategic effort to target children and adolescents. Therefore, having a non-comprehensive ban would allow opportunities for tobacco company to creatively advertise their products on unregulated channels such as advertisement at point of sales and online. Hence, as previously concluded by a study of 22 countries of the Organization for Economic Cooperation and Development Countries (Saffer \& Chaloupka, 2000), having only a partial ban may not lead to meaningful reduction in tobacco smoking.

\section{Strengths and Limitations}

This study compares two cities with and without bans on tobacco advertisement in East Java, where tobacco is a major industry. The study includes all types of advertisement and facilities used by children and adolescents in the study area. Thus, this study presents a more realistic and detailed view of OTAs surrounding children and adolescents. Although we did not compare between a location with a total OTA ban against a location with a partial ban, we were able to find that the partial ban created impact much smaller than that expected from a total ban. Assessing only one district each for those with and without OTA ban did not allow for a statistical comparison of OTA numbers and density between locations. Although we may not be able to generalise the results to all of Indonesia, this study can show the urgent need for a total ban on OTAs to limit the possibility of creative methods of advertisement.

\section{Policy Implications}

Outdoor tobacco advertising in Surabaya needs to be controlled rigorously. Although the number of OTAs in Banyuwangi was lower than that in Surabaya and lower than that in 2017, there were still violations of the regulation, and OTA still accounts for half of all advertisements in this district. In addition, the OTA hotspot area in Banyuwangi was large and there were also creative responses to the regulation from the tobacco industry, as indicated by the increasing percentage of store-affiliated advertisements and the use of SRC and GGSP symbols. These facts indicate the need for a total ban on OTAs, not just in areas where children and adolescents gather, but also especially at point of sale, or even better, a total prohibition for tobacco companies to advertise their products in any form.

It is noteworthy that in the national mid-term development plan 2020-2024, the government of Indonesia set a total ban on tobacco advertisement and promotion as a strategy to reduce the prevalence of smoking in adolescents (10-18 years old) to $8.7 \%$ by 2024 (National Development Planning Board of the Republic of Indonesia, 2019). The total ban on advertisements, however, means that the government should update the clause on Government Regulation No. 109/2012 that currently allows advertisement at the point of sale. The clause not only weakens the effort to control OTAs placed on stores but also undermines the effort to ban all advertising at the point of 
sale. It is important to note that a study in Indonesia found that tobacco advertisement at the point of sale starts to link the advertisement to the Internet and social media (Astuti et al., 2019). In addition, a study in the United States reported that exposure to Internet pro-tobacco advertisements doubled from 2000 to 2012 (Agaku et al., 2014). This indicates the need for Indonesia to establish comprehensive ban; not only a total ban on outdoor, printed and TV advertisement of tobacco but also a total ban on tobacco advertisement on the Internet and social media.

This study also suggests that monitoring only large- and medium-sized billboards and banners is very limiting for Indonesia. Further studies should consider mapping all types and sizes of advertisement and tobacco retailers with OTAs as well as online advertisements.

\section{Funding Details}

This study was funded by Universitas Airlangga's Riset Mandat Grant No. 360/UN3.14/LT/2019

\section{Acknowledgement}

The authors wish to thank the local government of Banyuwangi and Surabaya.

\section{Conflict of Interests}

All authors declared no conflict of interest

\section{References}

Adjoian, T., Dannefer, R., \& Farley, S. M. (2019). Density of outdoor advertising of consumable products in NYC by neighborhood poverty level. BMC Public Health, 19(1479), 1-9.

Agaku, I. T., King, B. A., \& Dube, S. R. (2014). Trends in exposure to pro-tobacco advertisements over the Internet, in newspapers/magazines, and at retail stores among U.S. middle and high school students, 2000-2012 [Journal Article]. Preventive Medicine, 58, 45-52. https://doi.org/https://dx.doi.org/10.1016/j.ypmed.2013.10.012

Astuti, P. A. S., Kurniasari, N. M. D., Mulyawan, K. H., Sebayang, S. K., \& Freeman, B. (2019). From glass boxes to social media engagement: an audit of tobacco retail marketing in Indonesia. Tob Control, 30, 30. https://doi.org/https://dx.doi.org/10.1136/tobaccocontrol-2018-054833

Badan Penelitian dan Pengembangan Kesehatan Kementerian Kesehatan Republik Indonesia. (2016). Laporan Survei Indikator Kesehatan Nasional (Sirkesnas) 2016 (

Badan Penelitian dan Pengembangan Kesehatan Kementerian Kesehatan Republik Indonesia. (2019). Laporan Nasional Riskesdas 2018 (

Badan Pusat Statistik Kabupaten Banyuwangi. (2018a). Kecamatan Banyuwangi Dalam Angka 2018. Badan Pusat Statistik Kabupaten Banyuwangi.

Badan Pusat Statistik Kabupaten Banyuwangi. (2018b). Kecamatan Giri Dalam Angka 2018. Badan Pusat Statistik Kabupaten Banyuwangi.

Badan Pusat Statistik Kabupaten Banyuwangi. (2019). Kabupaten Banyuwangi Dalam Angka 2019 [Banyuwangi Regency in Figures 2019]. Badan Pusat Statistik Kabupaten Banyuwangi.

Badan Pusat Statistik Kota Surabaya. (2017). Kota Surabaya Dalam Angka 2017 [Surabaya Municipality in Figures 2017). Badan Pusat Statistik Kota Surabaya.

Badan Pusat Statistik Kota Surabaya. (2018). Kecamatan Mulyorejo Dalam Angka 2018. Badan Pusat Statistik Kota Surabaya.

Badan Pusat Statistik Kota Surabaya. (2019). Kecamatan Sukolilo Dalam Angka 2019. Badan Pusat Statistik Kota Surabaya. 
Balappanavar, A. Y., Mohanty, V., \& Hussain, A. (2017). Compliance with Tobacco Promotion and Sale Laws in School Neighbourhoods in India [Journal Article]. Asian Pacific Journal of Cancer Prevention: Apjcp, 18(2), 563-570.

Center for Agricultural Data and Information System. (2019). AGRICULTURAL STATISTICS 2019 (

Chido-Amajuoyi, O. G., Mantey, D. S., Clendennen, S. L., \& Perez, A. (2017). Association of tobacco advertising, promotion and sponsorship (TAPS) exposure and cigarette use among Nigerian adolescents: implications for current practices, products and policies. BMJ Glob Health, 2(3), e000357. https://doi.org/10.1136/bmjgh-2017000357

Ikatan Ahli Kesehatan Masyarakat Indonesia. (2017). Kerjasama Industri Produk Tembakau dengan Ritel Tradisional lewat Program Insentif: Studi Kasus di 4 Kota yang berbatasan dengan Provinsi DKI Jakarta, 2016(

KoboToolBox. (2012). KoboCollect (Version v1.14.0a). KoboToolBox.

Megatsari, H., Ridlo, I. A., Amir, V., \& Kusuma, D. (2019). Visibility and hotspots of outdoor tobacco advertisement around educational facilities without an advertising ban: Geospatial analysis in Surabaya City, Indonesia [journal article]. Tobacco Prevention \& Cessation, 5(October). https://doi.org/10.18332/tpc/112462

Mistry, R., Pednekar, M. S., McCarthy, W. J., Resnicow, K., Pimple, S. A., Hsieh, H.-F., Mishra, G. A., \& Gupta, P. C. (2019). Compliance with point-of-sale tobacco control policies and student tobacco use in Mumbai, India. Tobacco Control, 28(2), 220-226. https://doi.org/10.1136/tobaccocontrol-2018-054290

National Development Planning Board of the Republic of Indonesia. (2019). [Preliminary Design of Indonesian National Mid-Term Development Plan 2020 - 2024] (

Nichter, M., Padmawati, S., Danardono, M., Ng, N., Prabandari, Y., \& Nichter, M. (2009). Reading culture from tobacco advertisements in Indonesia. Tobacco Control, 18(2), 98-107. https://doi.org/10.1136/tc.2008.025809

Oxoli, D., Prestifilippo, G., Bertocchi, D., \& Zurbaràn, M. (2017). Enabling spatial autocorrelation mapping in QGIS: The Hotspot Analysis Plugin. GEOINGEGNERIA AMBIENTALE E MINERARIA, 151(2), 45-50.

Picard, R. (2010). GEONEAR: Stata module to find nearest neighbors using geodetic distances. Boston College Department of Economics.

Prabandari, Y. S., \& Dewi, A. (2016). How do Indonesian youth perceive cigarette advertising? A cross-sectional study among Indonesian high school students. Global Health Action, 9, 10.3402/gha.v3409.30914. https://doi.org/10.3402/gha.v9.30914

Robertson, L., Cameron, C., McGee, R., Marsh, L., \& Hoek, J. (2016). Point-of-sale tobacco promotion and youth smoking: a meta-analysis. Tobacco Control, 25, e83-e89.

Robertson, L., McGee, R., Marsh, L., \& Hoek, J. (2015). A Systematic Review on the Impact of Point-of-Sale Tobacco Promotion on Smoking. Nicotine \& Tobacco Research, 2-17.

Saffer, H., \& Chaloupka, F. (2000). Density of outdoor advertising of consumable products in NYC by neighborhood poverty level. Journal of Health Economics, 19, 1117-1137.

Sebayang, S. K., Dewi, D., Lailiyah, S., \& Ahsan, A. (2018). Mixed-methods evaluation of a ban on tobacco advertising and promotion in Banyuwangi District, Indonesia. Tob Control. https://doi.org/10.1136/tobaccocontrol-2018-054443

Sebayang, S. K., Rosemary, R., Widiatmoko, D., Mohamad, K., \& Trisnantoro, L. (2012). Better to die than to leave a friend behind: industry strategy to reach the young. Tobacco Control, 21(3), 370-372. https://doi.org/10.1136/tobaccocontrol-2011-050223

Sundari, L., Zein, I. M., \& Kowi, I. (2017). Potret Buram 10 Kota Dikelilingi 2868 Iklan Rokok: Hasil Monitoring Iklan, Promosi \& Sponsor Rokok Oleh Forum Anak di 10 Kota/Kabupaten. Y. L. Anak

World Health Organization, R. O. f. S.-E. A. (2015). Global Youth Tobacco Survey (GYTS): Indonesia report, 2014 (

Yulianty, V., Yudiastuti, S., Haksama, S., \& Putri, T. S. (2011). Studi Tentang Pendapatan Daerah dari Advertensi Tembakau di Semarang, Surabaya dan Pontianak 
Table 1. Numbers of Outdoor Tobacco Advertisements (OTAs) in Banyuwangi and Surabaya

\begin{tabular}{|c|c|c|c|c|c|c|c|c|}
\hline \multirow[b]{2}{*}{ Variable } & \multicolumn{4}{|c|}{ Banyuwangi } & \multicolumn{4}{|c|}{ Surabaya } \\
\hline & $\begin{array}{c}\text { No. of } \\
\text { advertisem } \\
\text { ent points }\end{array}$ & $\%$ & $\begin{array}{c}\text { No. of } \\
\text { advertise } \\
\text { ments }\end{array}$ & $\%$ & $\begin{array}{c}\text { No. of } \\
\text { advertise } \\
\text { ment } \\
\text { points }\end{array}$ & $\%$ & $\begin{array}{c}\text { No. of } \\
\text { advertise } \\
\text { ments }\end{array}$ & $\%$ \\
\hline Total number of OTAs & 1,301 & & 1,838 & & 2,339 & & 3,700 & \\
\hline Population number & 139,734 & & 139,734 & & 203,188 & & 203,188 & \\
\hline Number of population aged $0-19$ years & 41,823 & & 41,823 & & 58,490 & & 58,490 & \\
\hline Area $\left(\mathrm{km}^{2}\right)$ & 51.2 & & 51.2 & & 35.6 & & 35.6 & \\
\hline OTAs $/ \mathrm{km}^{2}$ & 25.4 & & 35.9 & & 65.7 & & 103.9 & \\
\hline OTAs/1,000 children and adolescents & 31.1 & & 43.9 & & 40.0 & & 63.3 & \\
\hline \multicolumn{9}{|l|}{ By type } \\
\hline Banner & 738 & 56.7 & 910 & 49.5 & 941 & 40.2 & 1,191 & 32.2 \\
\hline Poster & 454 & 34.9 & 779 & 42.4 & 912 & 39.0 & 1,487 & 40.2 \\
\hline Store name board & 49 & 3.8 & 53 & 2.9 & 130 & 5.6 & 131 & 3.5 \\
\hline Sticker & 35 & 2.7 & 70 & 3.8 & 132 & 5.6 & 259 & 7.0 \\
\hline Billboard & 10 & 0.8 & 10 & 0.5 & 42 & 1.8 & 58 & 1.6 \\
\hline Other & 15 & 1.2 & 16 & 0.9 & 182 & 7.8 & 574 & 15.5 \\
\hline \multicolumn{9}{|l|}{ By company } \\
\hline Djarum & 444 & 34.1 & 652.0 & 35.5 & 477 & 20.4 & 946 & 25.6 \\
\hline Gudang Garam & 328 & 25.2 & 378.0 & 20.6 & 379 & 16.2 & 535 & 14.5 \\
\hline HM Sampoerna/Philip Morris International & 154 & 11.8 & 185.0 & 10.1 & 309 & 13.2 & 478 & 12.9 \\
\hline Karya Dibya Mahardika/Japan Tobacco Inc. & 139 & 10.7 & 231.0 & 12.6 & 435 & 18.6 & 727 & 19.6 \\
\hline Bentoel Group/British American Tobacco & 110 & 8.5 & 189.0 & 10.3 & 128 & 5.5 & 149 & 4.0 \\
\hline Other & 126 & 9.7 & 203 & 11.0 & 611.0 & 26.1 & 865 & 23.4 \\
\hline
\end{tabular}


Table 2. Density of Neighbouring Outdoor Tobacco Advertisements (OTAs) Near Facilities Used by Children and Adolescents in Banyuwangi and Surabaya

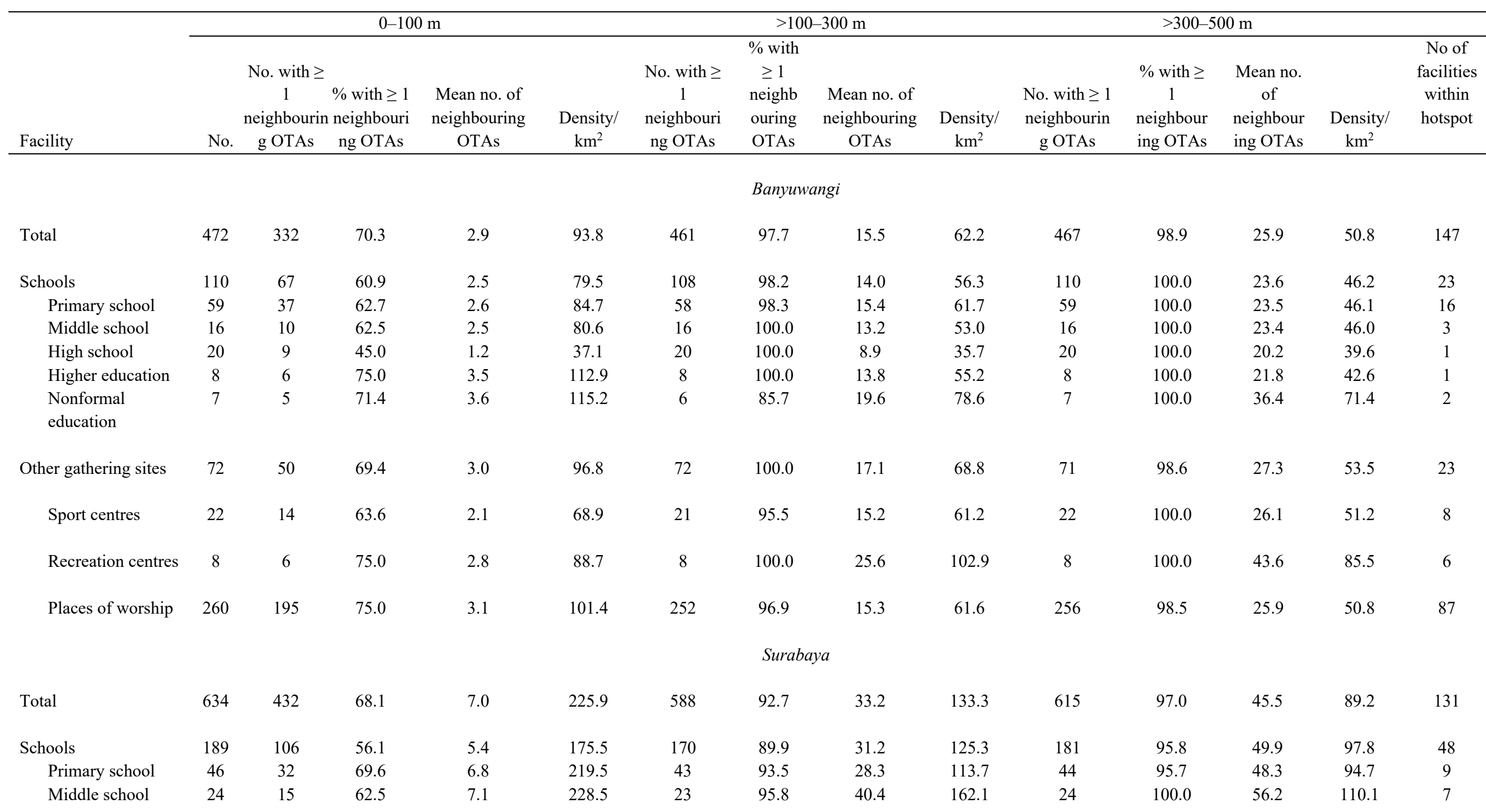


Accepted December 2020: Global Public Health

\begin{tabular}{|c|c|c|c|c|c|c|c|c|c|c|c|c|c|c|}
\hline High school & 26 & 15 & 57.7 & 5.3 & 170.0 & 22 & 84.6 & 35.2 & 141.2 & 24 & 92.3 & 55.0 & 107.8 & 8 \\
\hline Higher education & 23 & 16 & 69.6 & 6.3 & 203.4 & 22 & 95.7 & 35.8 & 143.9 & 23 & 100.0 & 54.2 & 106.3 & 8 \\
\hline $\begin{array}{l}\text { Nonformal } \\
\text { education }\end{array}$ & 70 & 28 & 40.0 & 3.8 & 121.2 & 60 & 85.7 & 27.0 & 108.4 & 66 & 94.3 & 45.4 & 89.1 & 16 \\
\hline Other gathering sites & 202 & 141 & 69.8 & 7.3 & 234.3 & 186 & 92.1 & 33.9 & 136.1 & 198 & 98.0 & 41.2 & 80.7 & 34 \\
\hline Sport centres & 42 & 19 & 45.2 & 2.0 & 63.0 & 36 & 85.7 & 20.6 & 82.9 & 38 & 90.5 & 44.6 & 87.5 & 5 \\
\hline Recreation centres & 2 & 1 & 50.0 & 6.0 & 193.5 & 2 & 100.0 & 17.0 & 68.3 & 2 & 100.0 & 78.5 & 153.9 & 1 \\
\hline Places of worship & 199 & 165 & 82.9 & 9.3 & 299.9 & 194 & 97.5 & 37.2 & 149.2 & 196 & 98.5 & 45.6 & 89.3 & 43 \\
\hline
\end{tabular}


Figure 1. Hotspots of number of outdoor tobacco advertisement (OTA) points in Banyuwangi and Surabaya

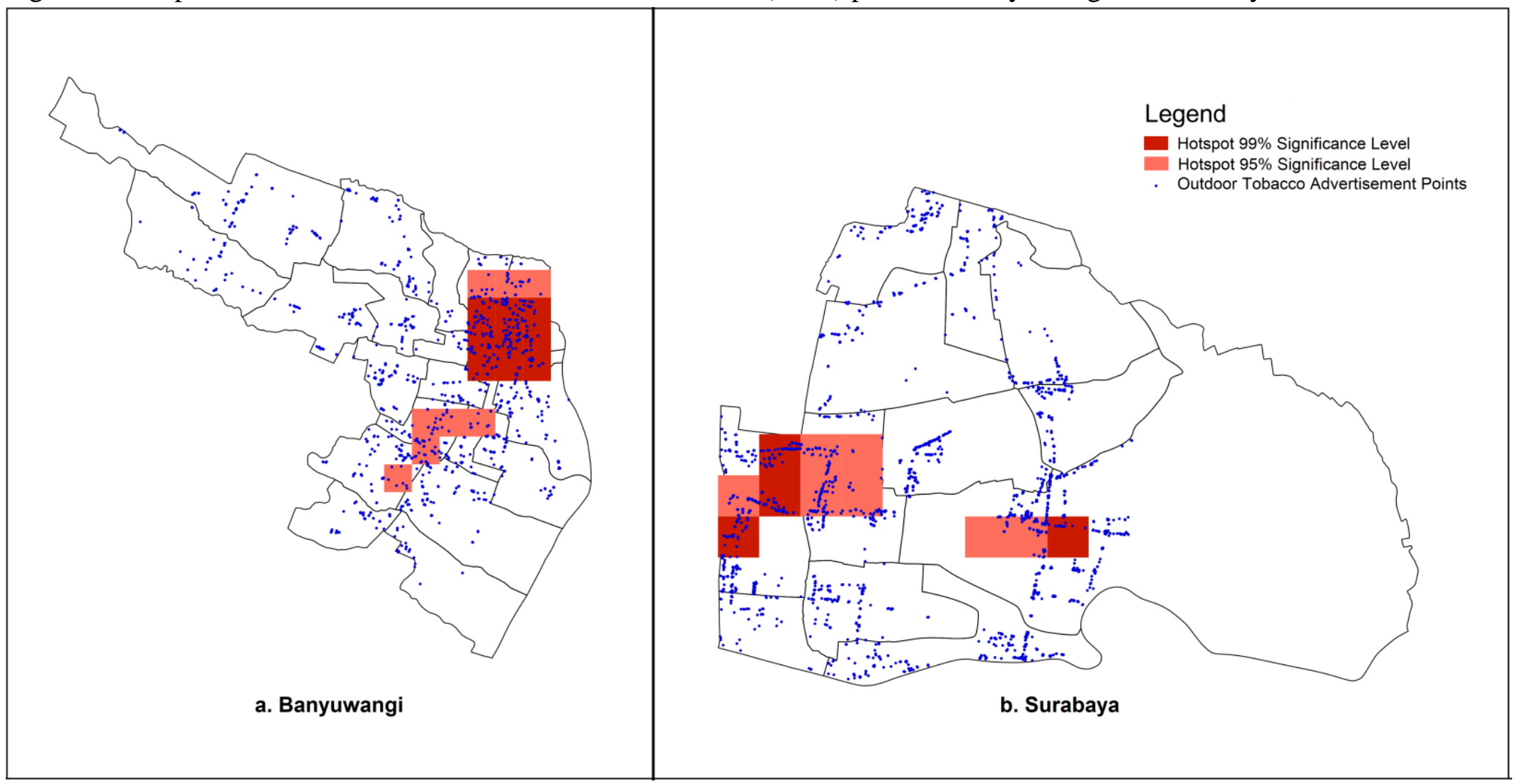


Figure 2. Hotspots of number of outdoor tobacco advertisement (OTA) points by hotspots of tobacco retailer and facility used by children and adolescents in Banyuwangi and Surabaya

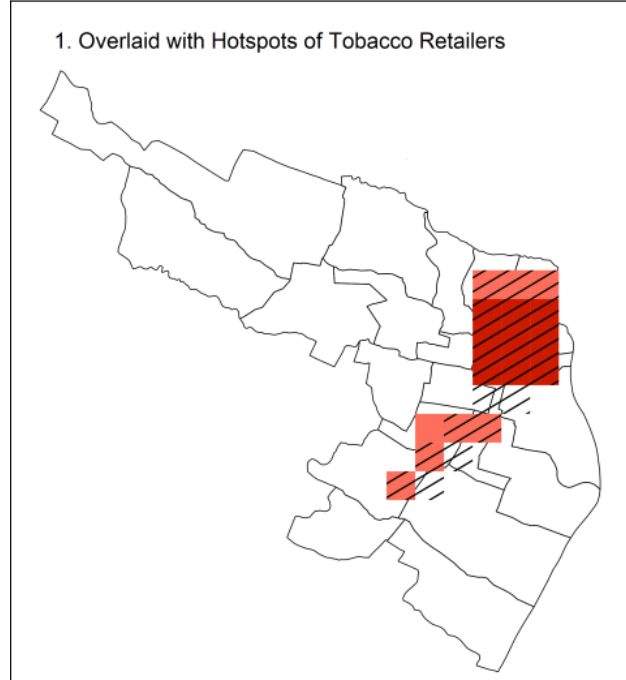

a. Banyuwangi

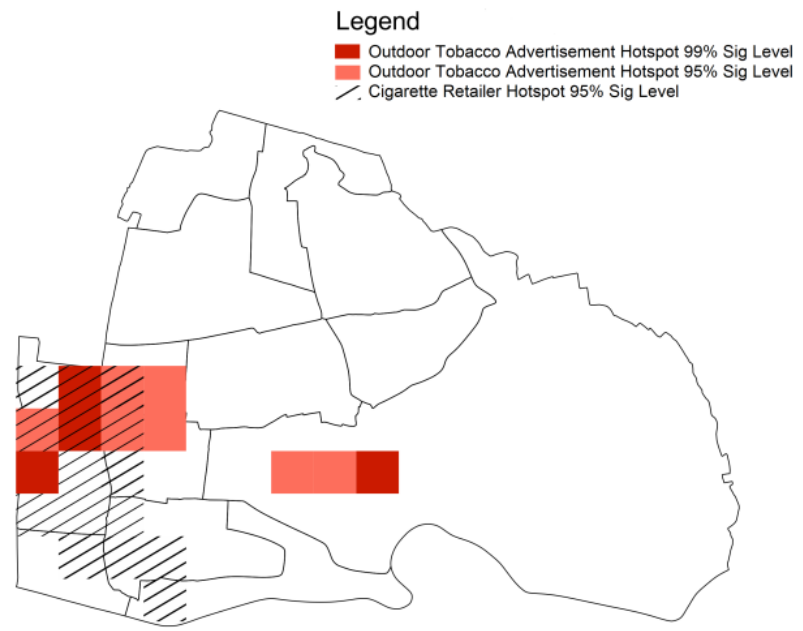

b. Surabaya

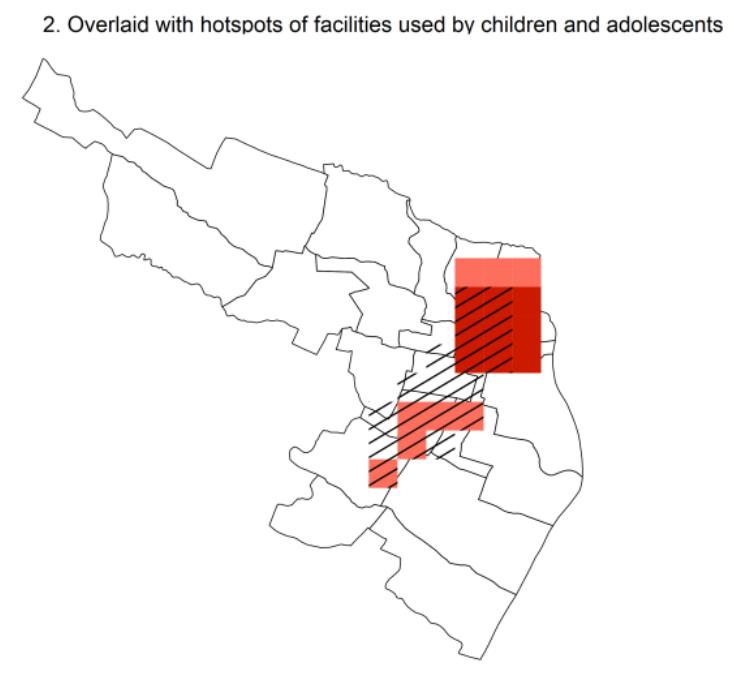

a. Banyuwangi

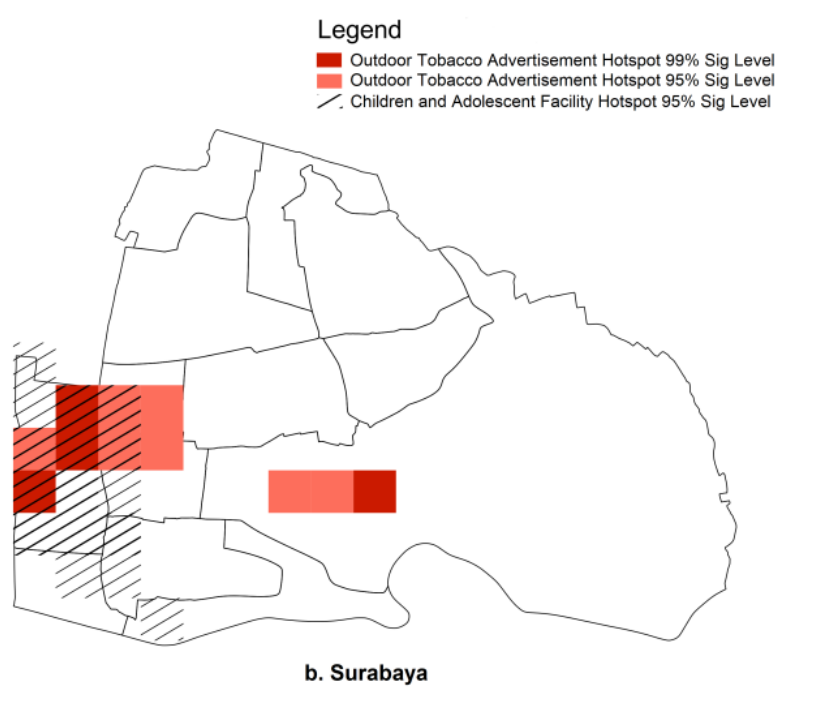

